\title{
WOUNDED WARRIOR RESCUING THAKUR RAM FROM DEADLY EPIDEMIC
}

\author{
Sajan Kumar Karn \\ Department of English Education
}

He who rejects change is the architect of decay. The only human institution that rejects the progress is the cemetery.

Harold Wilson

\begin{abstract}
Educational institutions are considered change agents for they are shouldered with the responsibility of transforming individuals, society, nation and also the world. Nevertheless, what happens if the change agents themselves do not conform to the changes has been well said by Wilson in the above quote. There is no doubt to the fact that education around the globe has undergone sea changes in perspectives and practices both but Thakur Ram Multiple Campus, Birgunj, one of the biggest educational foundations in the country that had its name and fame for the academic brilliance in the times of yore, feels to be driving the same bullock carts while sports cars are being rolled down around the globe. In this composition, I have endeavored to unveil those orthodox practices, as I have perceived, against the backdrop of the breaking educational paradigms and propose to deconstruct conformist prototypes to prevent it from being more infamous.
\end{abstract}

\section{Keywords}

Digital literacy, banking education, subversive, paradigm, critical thinking

\section{Background}

Nobody would probably deny that established in 1952 A.D., Thakur Ram Multiple Campus ${ }^{1}$ Birgunj bears an impressive past but a tough present and has envisaged even a tougher future. A pioneer higher level academic institution not merely in the central Terai but in the entire country, the campus is almost sixty years old today, even older than Tribhuvan University, which was founded in 1959. Does 'growing old' mean 'growing up' too? Of course, not. To me, they are two

1 Thakur Ram will be used in the rest of document to refer to Thakur Ram Multiple Campus

Birgunj to maintain economy in using words. 
different things. If Thakur Ram is merely growing old, not growing up, that must be a matter of concern. Upon the completion of five long decades, it observed its golden jubilee in 2002 with pomp and enthusiasm. Swarna Jayanti Smarika (2002) is full of gratifying adjectives on the glorious past of the campus. We, the teachers, students and also staff never get tired of bragging that TRM campus is an A class constituent campus of Tribhuvan University that has produced for the nation- patriotic statesmen, well-known literary figures, distinguished scholars, celebrated artists, kind hearted social workers, prosperous industrialists, renowned doctors and skilled technical manpower in six decades of time. I wonder if it is wise to keep diving into splendid anteriority overlooking the dreadful present and even more terrible posterity that it has envisaged.

About a decade of my association with the campus via different academic activities, thorough observations, interactions amongst faculties, students and staff and my own personal scrutiny of the situations reveals that Thakur Ram has not taken the directions it should have. It has grown more quantitatively than qualitatively. The mushrooming enrollment (above 7 thousands students altogether), a large number of teachers (above 150) and administrative staffs (above 105) to look after them gives an impression as if Thakur Ram were a university in itself. From dawn to dusk, in fact, till eight at night it offers its untiring services. An enormous row of motorbikes and scooters on its premises. The majority in a hurry to deposit the hard committed treasure to the tabula rasa. Some sweating in the classrooms, others gossiping in the gardens, still others making their fortunes elsewhere. The campus earned them an identity which they are cashing in the flea markets. Even larger number of bicycles, and pedestrians hurrying to illuminate their lives. God knows if they run off the campus being enlightened. The account section pretty occupied in disbursing the wages to the depositors and accumulating fees and dues, the exam section always readying for the most democratic examination in the most democratic time of Nepal. Everyone envies the unequaled freedom exam section possesses and so do I. Facilitators -some well known for honesty, others nodding on plastic chairs. Loktantra in the country has liberated all so much so that they have put out of their mind the obligations they are required to abide by. Students-some learning, others earning elsewhere, still others busy politicking. The panorama is pretty hectic but all feel extremely simulated. However, gardens with red, pink, and golden flowers, some white with red or pink tapestries, others with blue and even black ones on the campus premises, as they always are, feel very vigorous and refreshing. As real and natural as they are. Thanks to the gardeners for not letting the flowers fade even during summer.

Forget not, the campus has already been proposed for its promotion as the base campus of auniversity tobefoundedin Birgunj. Viewing quantitatively-its physical infrastructures, feeder institutions, geographical suitability and support from outside, the campus does qualify to be promoted as a jumbo jet. Nonetheless, what happens if its fuel is of low quality, its pilots have meager eyesight, its crews are unacquainted with and unresponsive towards the latest renovations in the engine, the weather is overcast and it encroaches passengers like a local bus? Are we ready to break the wall of Berlin on the way which is likely to cause a mishap any moment? We must be because we do not want Thakur Ram to become a sinking Titanic, do we?

\section{Wounded warrior truly it is!}

What, if not wounded warrior? Yes, Thakur Ram is brutally wounded by numerous prickly arrows as Bhimsmpitamah was in Mahabharata by his own kith and kin. It is all evident that the pyramid of students, teachers and administrative staff are responsible for both rise and fall of an academy. To put it other way, if an institution prospers or goes down, it 
is always because of smooth coordination of this pyramid. The pyramid of Thakur Ram, however, does seem to be shattering. Once this starts functioning well, the heydays are not far away. I do not blame one side of the pyramid exclusively responsible for the problem though. I think the basic reason has been there is lack of belongingness towards the institution. First, we need to create in our hearts and minds that Thakur Ram is ours and we belong to ThakurRam. It has earned not only bread and butter for us but also an identity, in fact the most precious thing, the thing by which we live. We have been sellable elsewhere only because of this identify. Unless this sense of belongingness could be built up this in the triangularly connected sides, Thakur Ram is bound to remain wounded.

I do not even aim to penetrate into those issues that have any concern with politics, though the campus has turned into a battlefield of politicking is all obvious. I prefer to concentrate merely on academic issues which I think are pushing campus into a gigantic ditch day by day. I am saying all this because I love Thakur Ram more than anything else. It is in every breath of mine and I am concerned about its present and future both. The academic evils can be experienced in the deficient quality of teaching that it offers, teaching and learning atmosphere that it has provided to teachers and students, so called examination system it continues with, indifferent attitudes towards professional capacity building programs, apathy for research and innovations that it should have given priority over, library enrichment and management and most importantly lack of due efforts towards digitization of teaching and learning that has brought ground breaking changes in education around the globe.

\section{Breaking paradigms but creaking Thakur Ram}

Needless to say that there have been a lot of shifts in teaching and learning around the globe. Technological intervention in education, rupture of hierarchy in classroom, learners' autonomy, dawn of critical thinking, subverting of education, research triggered teaching etc. are some of the breaking paradigms in education home and abroad. However, Thakur seem to have turned virtually a deaf ear to most of the shifts, which should be a matter of big worry for one and all. In the section below, I assess Thakur Ram against the backdrop of these measures.

\section{Open and free knowledge}

Imagine a world in which every single person on the planet is given free access to the sum of human knowledge. That's what we're doing.

Jimmy Wales, Wikipedia Founder (2004)

The above statement is not merely informative but it triggers some immediate actions on the part of conscious individuals in general and academia in particular. What about ours? Is our campus equipped with digital tools to be used in classroom? Are our teachers literate enough to exploit digital tools to make their instructions effective? Can we sustain and grow in the absence of such tools?

Thomas Friedman wrote in The World is Flat "We are now in the process of connecting all of the knowledge pools in the world together" (Freidman, 2005). Likewise, Walter Ong(1982) suggests that these technologies are not just changing our lived conditions they are chainging the way that we think. Pat Sullivan (1991) claims that these new technologies are 'change agents' (Cited in Swenson et al. 2006). We must also be aware of the fact that "Google is currently attempting to scan and digitize more than 50 million books from the five of the largest research libraries from around the world" (Richardson, 2009, p.129). Internet is exploding by leaps and bounds. Library of Congress is all set to digitize 500 million volumes. This is truly the most transformative events in the history of information distribution. 


\section{S.K Karn}

Karn (2011, p. 34) advocates the importance of digital literacy in education in the following words:

Conventionally, one needs to be able to read and write in order to be called literate. Of course, those core abilities are still vital to learning, but they are no longer adequate to ensure comprehensive understanding of the present day world. Today we live in a digitally networked atmosphere where a large number of things happen online and envisioning academic endurance and growth in paucity of access to and knowhow of digital tools will be nothing but an utter innocence.

The massive use of technology in education around the globe has raised a serious question mark over the literacy of majority of Nepalese teachers including those from Thakur Ram. This is high time we pondered over the reliteracy of our teachers.

It is worth quoting Senson et al. (2006) who state that "that new digital technologies require both old and new sets of literacies and social practices, including both printbased and multimodal literacies and their accompanying social practices. Thus, it is not a matter of readers developing either print or digital reading skills; new literacies are in a synergistic, reciprocal, and constantly evolving relationship with older literacies, and the interplay of these processes in support of communication and knowledge construction must be perceived as social acts that build upon prior knowledge, literacy skills, and social literacy practices" (p. 357).

Similarly, can we imagine a classroom as Harmer (2002, p.175) describes below?

If you walk into some classrooms around the world, you will see fixed data projectors, interactive whiteboards (IWBs), built- in speakers for audio material that is delivered directly from a computer hard disk, and computers with round -the -clock internet access. Whenever teachers want their students to find anything out, they can get them to use a search engine like Google and the result can be shown to the whole class on the IWB.

No doubt, such a classroom is beyond our imagination. Whereas some teachers do with chalk and duster, others deliver their sermons in the field basking their body in the sun. Our classroom is not quite different from Gurukul tradition of education. Desk-benches along with a black blackboard. That's it. But it is high time the campus realized that this needs to be subverted. Ignoring the digital boom merely infers wearing tree barks during the suit generation. The campus needs to digitize class rooms as well with digital tools.

A point to be noted however, is that in the name of digitization, the campus has recently purchased an LCD projector and a research centre established on its library premises does have a couple of desktop computers, Xerox machine, scanner etc. Similarly, Master's program of the campus has assisted financially those teachers willing to buy laptops. This is of course a good sign, and a very positive step, however, we cannot be and must not be satisfied with it. Every department should be equipped with at least a couple of laptops, LCD projectors, and a printer so that department can work independently, faculties can exploit them in the classrooms with PowerPoint presentation etc.. Again equipping departments is not all, teachers are required to be trained to exploit those tools inside and outside classrooms.

Karn (2011, 35-36) describes the situation of Nepalese education in general and it fits Thakur Ram as well.

We are in our well dry-cleaned suits and ties, shiningly polished shoes, helmets on our heads and mobile phones in our hands and we introduce ourselves as university teachers. Nonetheless, we complain about the lack of technological resources or internet connection in our departments, we do not have an email account, nor a Facebook or Skype account, nor have 
we used or contributed to flickr, posted a message on Twitter, nor learnt how to download teaching materials from educational websites, not to mention whether our universities have free access to academic journal databasesfor free-and we are not able to prepare for a class or a presentation by using a simple PowerPoint slide, we do not have personal blogs to share ideas, we do not know how to download from and upload videos on media sharing sites like YouTube and we do not have any idea about wikis and we cannot create web documents like Google Docs and collaboratively draft anything with others. All these and many others skills are beyond our capabilitiesactually, they are beyond our interest or sense of need-but still, don't worry, we are university professors, associate professors and assistant professors of education, science and management.

Today's academia demands that teachers are connectors, content creators and collaborators. It is imperative for educators to model strategies, to not only find worthwhile and relevant content, but to use primary sources in the classroom. A teacher can invite people from around the world to engage in discussions and even content creation via blogs, wikis and podcasts.

\section{Good lecturers are bad teachers}

Gone are the days when teachers used to enter the classrooms, delivered long sermon like lectures and their students lent all ears to them as good audience of Bhagbad Saptah. Omniscient teachers and ignorant students' culture must vanish if teaching is a humanized activity. Lecture creates a hierarchy between teachers and students, which inhibits learners. It treats education similar to banking. "Education becomes an act of depositing, in which the students are depositories and the teacher is the depositor" (Freire, 1975, 45). This narrative character of education makes education authoritative, and thus suppresses the inherent talents of the students. We observed earlier that technology has made contents all open. Therefore, it is very paradoxical for teachers to consider themselves as the authorities of information while it is just a click away at Google search or Wikipedia.com. Technology has transformed teaching from lecture to conversation. Siemens (2002) is right to say that ideas are presented as the starting point for dialogue, not the ending point. There is a call for a lot of interaction and discussion between a teacher and students to reach conclusions. Unfortunately, my observations reveal that committing and vomiting is the pet technique of most of the teachers. The role of teacher merely as content sharer has virtually killed the true meaning of education. Osho is worth mentioning here again: "A teacher imparts information, knowledge, skills and techniques to a student, the student pays for these to pass examination and get a job or to go in business, It is a business like relationship"(2005, p.18). A true education is to bring out what is hidden in students, i.e. the inherent potentialities. This requires conversation which is interactive, which bestows freedom to students and provides atmosphere to do things critically and also creatively. Lectures are merely informative. This needs to be deconstructed if we want to do realistic education.

In a typical classroom, we find as Freire (1975, p. 46-47) states:

- The teacher teaches and students are taught.

- The teacher knows everything and the students know nothing.

- The teacher thinks and the students are thought about.

- The teacher talks and the students listenmeekly.

- The teacher disciplines and the students are disciplined.

- The teacher chooses and enforces his choices, and the students comply. 


\section{S.K Karn}

- The teacher acts and the students have the illusion of acting through the action of the teacher.

- The teacher chooses the programme content, and the students adapt to it.

- The teacher confuses the authority of knowledge with his own professional authority, which he sets in opposition to the freedom of the students.

- The teacher is the subject of the learning process, while pupils are mere objects.

If these are our principles, we are the best depositors but of course bad teachers. Time has come to abandon these old habits and start a new culture of interface, and discussion that is horizontal and hierarchy free.

\section{Teaching contents or thinking?}

Plutarch observed long back that "the mind is not a vessel to be filled but a fire to be kindled" (Cited in Halonen, 2006, p. 319. A child's mind is not a tabula rasa i.e. a blank sheet of paper that teacher can imprint whatever he/she wishes to. They hold expectations, experiences and conceptions that will shape their interpretation of the knowledge a teacher presents to him. Unfortunately, filling vessels has been a preferred strategy of most of the teachers of colleges including Thakur Ram. "Learner- centered teachers embrace the responsibility for fostering changes in students' thinking skills. They believe that students' grappling with ideas will lead to more meaningful and enduring learning.

Until now, we have only taught contentsmere information. This is of course debatable if content is worth teaching but one thing is for sure that without teaching thinking we can never make learning realistic and relevant to our society. Mere content teaching has made our education one way traffic. We have hardly ever made our students think on our local academic or life related issues and figure out solutions for them. This is the biggest defect of our education, I suppose. We must aim our students to bring difference in existing situation but conversely, our teaching has merely inferred memorization for reproduction in the exams. Bloom's taxonomy of educational objectives put memorization/ remember as a lowest order skill which might be appropriate only at lower level of education. College level education should aim at higher level thinking skills such as analysis, evaluation and creation. Further, college teachers are supposed to teach how to thinkthat is, how to become independent, selfdirected thinkers and learners. Let us look at this table of educational objectives.

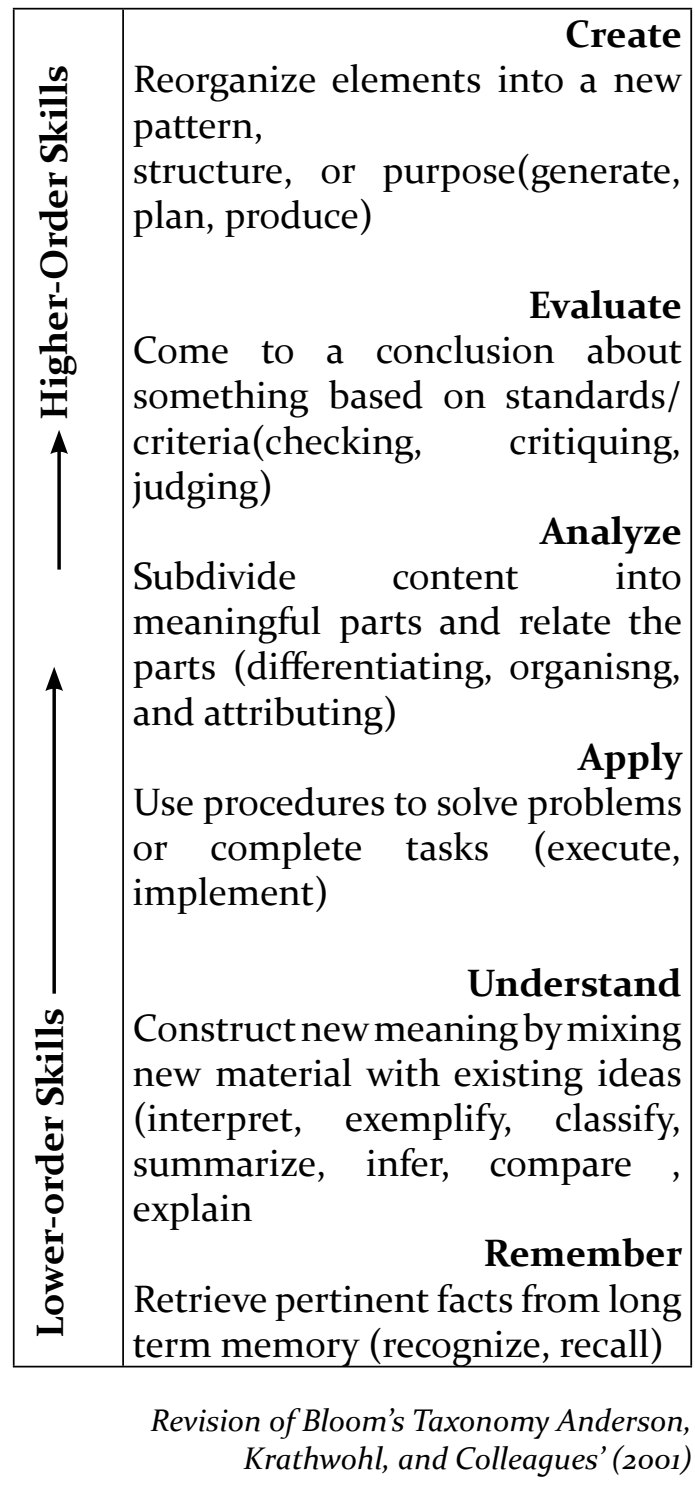


The main aim of education is practical and reflective judgment, a mind trained to be critical everywhere in the use of evidence (Blanchard, cited in Bassham et al, 2005, p. 8). About the benefits of critical thinking, Bassham et al (2005, maintain:

"It can help students do better in school by improving their ability to understand, construct, and criticize arguments. Itcan help people succeed in their careers by improving their ability to solve problems, think creatively, and communicate their ideas clearly and effectively. It can also reduce the likelihood of making serious mistakes in important personal decisions, promote democratic processes by improving the quality of public decision making, and liberate and empower individuals by freeing them from the unexamined assumptions, dogmas and prejudices of their upbringing, their society and their age"( p. 8).

Likewise, Lohani, Adhikari, Subedi and Gupto(2008) maintain that critical thinking helps us providing protection from other people's manipulation, lessening the likelihood of making serious mistakes in important decisions, and contributing in groups to better decision and consensus making, whether with family, friends, committees, action groups, co-workers or even with bosses(p.13). The most important thing about critical thinking is that it allows us to welcome life's problems as challenges to be solved.

This is the time to question our own practices? We, the teachers have to realize if our teaching has triggered students to think at all.

\section{What a student!}

If a teacher is indeed wise he does not bid you enter the house of his wisdom, but rather leads you to the threshold of your own mind.

Kahlil Gibran
Yes, a good teacher ever attempts to make his/her students independent-self directed learners. Self directed learners, according to Hedge (200o, p.76), have the following characteristics:

- know their needs and work, productively with the teacher towards the achievement of their objectives

- learn both inside and outside the classroom

- can take classroom based material and can build on it

- know how to use resources independently

- learn with active thinking

- adjust their learning strategies when necessary to improve their learning

- manage and divide the time in learning properly

- do not think the teacher is a god who can give them ability to master.....

Yes, of course, teachers are supposed to make their students independent. However, it is also on the part of students to understand that they do not depend heavily on teachers. They have to think and act independently as much as possible. Our students have been very much reliant and always expect teachers to give them notes. This readymade capsule or tablet based instruction does not take them anywhere except obtaining of a certificate.

Give a man a fish

He eats for a day

Teach him to fish

He eats for the whole life

This anonymous quote inspires teachers and students both. Teachers are required to think if they are giving their students fish or they are teaching them to fish. Observations reveal that majority of teachers including those of Thakur Ram have through lectures, explanations etc. made the pupils heavily reliant. This is the time they were made autonomous learners so that they take the charge of their learning. Again this is not feasible unless students 


\section{S.K Karn}

cooperate. They have to give up the habits of depending upon teachers for notes for exams.

\section{How subversive we are?}

"A teacher is that rare individual who coaxes the existing knowledge systems of his students out of hiding, drags every last tentacle of the monster from the depths into broad daylight, hoses off the slime, wrestles it to the ground when it puts up a fight, and finally gives it a heart transplant. That's subversion. That's teaching” (May, 200o).

You must be the change you want to see in the world, said Gandhi. Teachers are the agents of change. Postman and Weingartner (1969) shook some educational foundations with their blockbuster, Teaching as a Subversive activity. They challenged teachers to enable their students to become crap detectors. Yes, crap detectors in creating major changes in our social, economic and political systems. According to Brown (2007, p. 513) "those who teach languages may indeed have special responsibility to subvert attitudes and beliefs and assumptions that ultimately impede the attainment of such goals as equality, justice, freedom and opportunity". There are many including Osho (2005) who are of the opinion that education should be subversive and rebellious. Similarly, Fulan(1993) reiterates that teachers have the responsibility of change agents: "Moral purposeand changeagentry are implicit in what good teaching and effective change are about, but as yet they are society's (and teaching's) great untapped resources for radical and continuous improvement. We need to go public with a new rationale for why teaching and teacher development are fundamental to the future of society" (p. 11).

The time has come to evaluate if our education has been subversive at all. We must not keep sticking to the conventional trends if they do not fetch the expected results. Both our perspectives and practices have to be subverted in order to make education more productive. Students, teachers and staff all are required to think anew.

\section{Research and publication}

"All progress is born of inquiry. Doubt is often better than overconfidence, for it leads to inquiry, and inquiry leads to invention"

Hudson Maxim

There is no doubt to the belief that teaching and research should go together. Research guides teaching in a right direction. Teachers are professionals and a professional is supposed to bring change in the existing situation. Though Khaniya(2006) refers to professionalism of English language teachers, it suits teachers of all disciplines. He says "English teachers are, in principle, professionals because their responsibility is not confined only to perform tasks like a technicialn but it also involves responsibility for explaining why something works; for example, explaining and defining ..........It also involves innovation and critical thinking in the area of expertise, Research is a kind of diagnosis. As Kumar says 'research is a way of thinking: examining critically the various aspects of your day-to-day professional work; understanding and formulating guiding principles that govern a particular procedure; and developing and testing new theories for the enhancement of your practice"(2005, p.2). Likewise, Best and Kahn (1993) advocate that research is directed toward the solution of a problem. It is all obvious that our education suffers a lot and the crises can be addressed only if researches are carried out. Specifically, action research is very important for teachers. An action research places emphasis on a problem here and now in a local setting.

Similarly, in another text, Khaniya (2006) maintains that one of the major functions of the higher education is research and innovations. Research and publications are considered to be indicators of the advancement of the university.

Thakur Ram runs a large number of Master's level program. No doubt students carry out reserach and write theses. However, most seem to be instrumentally motivated. Additionally, 
even if theses do have some substantial things, they have merely decorated the shelves of the library. Teachers are also required to involve themselves in research activities to offer objective solutions to the problems arising in teaching and elsewhere.

It is of course good that this critically constructive article is being published in its own journal, journal of Thakur Ram. However, this tiny but historic initiative must not satisfy us up to the brim. There is a need that every department starts this venture independently. Most importantly, there is a dire need to give this work continuity and to upgrade its standards in next issues.

\section{What a library we have!}

Library plays a pivotal role in enhancing the quality of teaching and learning of an institution. A library usually have sections like-acquisition section, cataloguing section, circulation section, research section, journals and periodical section, internet section, reference section etc. A library is required not only supposed to include textbooks but it has to have different scholarly journals, magazines, newspapers, reference sections, study areas and so forth. If you visit the library of Thakur Ram, it leaves you with mixed impressions. On the one hand, it makes you imagine what a library it was, on the other hand, it also worries you with its pathetic situation. Lack of catalogues, all old books rotting in the shelves, no good space conducive for students and teachers to sit and read. The most unfortunate is that it is accumulating handbooks recently to meet students' need. This is the only campus library that does not possess any Masters' theses, project reports, practicum reports etc. It is truly very strange that every year some three lakhs of Nepalese currency are spent on books but the book drawers look virtually empty. A few students and teachers would be found in the library reading books. No internet access, no Xerox section. Poorly managed. Staffs allege students and campus administration responsible for it but again administration would escape putting the ball into others' court. It is hard to say who is exactly responsible for this mess.

Without enriching and managing library, we cannot expect researches and innovations to happen. Are we ready for this?

\section{Conclusion}

We have seen that Thakur Ram is plagued with a huge number of problems, some administrative (managerial), some academic and still others but politically motivated. In this article, I have pondered over some burning academic issues that need immediate attention. It is very important now to realize that we have to lay our utmost efforts to revitalize the campus with new vigor, new thoughts, and new determination. This is high time we, the teachers, changed our perspectives and practices both and students and staff do not merely seek for their rights but also understand their responsibilities in order to give Thakur Ram a true academic label. Since orthodox practices have merely pushed the campus backward, this is time we deconstructed those rotten practices and find an alternative model. I think the most important thing here is and should be that we all are required to take responsibility of duties and responsibilities with utmost sincerity. I would like to bring this paper to an end with a very inspirational Gandhian quote:

Live as if you were to die tomorrow Leave as if you were to live forever

\section{References}

Best, J. W. \& Kahn, J.V.(2004). Research in education. New Delhi: Prentice-Hall of India Private Limited.

Brown, H. D. (2001). Teaching by principles: an interactive approach to language padagogy. London: Prentice Hall.

Fredman, T. (2005). The world is flat: A brief history of the twenty first century. New York: Farr, Strauss and Giroux. 
Frieri, P. (1967). Pedagogy of the oppressed. New York: Herder and Herder.

Fullan, M. G.( 1993). The Professional Teacher: Why Teachers Must Become Change Agents. Educational Leadership, $50,6,1-12$.

Harmer, J. (2007). The practice of English language teaching. London: Pearson Longman.

Karn, S.K. (2011, February 5). Educated but Illiterate Teachers. The Rising Nepal. 4A.

Kumar, R. (2005). Research methodology . Delhi: Pearson Education.

Lohani, S., Adhikari, R., Subedi, A., \& Gupto, A. (Eds.). (2008). Critical andCreative thinking. Kathmandu: Educational Publishing House.

Richardson, W. (2009). Blogs, wikis, podcasts and other powerful web tools for classrooms. California: Corwin Press.

Osho (2005). Future of education. Osho world. New Delhi: Osho World Foundation.
...... (2006). Growing old, growing up. Osho world. New Delhi: Osho World Foundation.

Khaniya, T.R. (2006). New horizons in education in Nepal. Kathmandu: Kishore Khaniya.

..(2006). Professionalism of English Language Teachers. Young voices in ELT. Kathmandu: Department of English Education.

May, T. (2000). Teaching as a Subversive Activity. Retrieved on 10 July, 2011 from http://thormay.net/unwiseideas/teachers.html.

McKeachie, W. J. \& Svinicki, M. (2006). Teaching tips: strategies, research and theory for college and university teachers. New York: Houghton Mifflin Company.

Swenson, J., Young, C. A., McGrail, E. Rozema, R \& Whitin, P. (2006). Extending the conversation: New Technologies, New Literacies, and English Education. English Education, 38, 4, 352-368.

\section{The Author}

Sajan Kumar Karn is a Lecturer in English Education in Thakur Ram Multiple Campus, Birgunj where he has been teaching various courses in English and Applied Linguistics for about a decade. He has extensively published on education and ELT in newspapers and journals, has co-authored two titles on Applied Linguistics and has worked as one of the contributors in three prescribed texts on English literature. He has so far edited five volumes of 'ELT Today', Journal of NELTA Birgunj and has been contributing as an editor of NELTA Choutari, the web- magazine of NELTA. He participated in Study of the United States Institute (2009) program held in University of Florida, USA. He has presented and participated in a number of national and international conferences on ELT and linguistics. His areas of concern include Nepalese academia in general and Nepalese ELT in particular.

Email: greatsajankarn@gmail.com 